\title{
Skrining Inhibitor NF-kB Combretum indicum dengan Metode Docking
}

\section{Screening Of Inhibitor NF-kB Combretum indicum with Docking Method}

\author{
Samsul Hadi*, Amalia Khairunnisa, Sefa Nur Khalifah, Sintya Oktaviani, Sri Oktaviana Sari, Umi Nur \\ Hapifah \\ Prodi Farmasi, FMIPA, Universitas Lambung Mangkurat , Jl. Brigjen. H. Hasan Basry Kayu Tangi, \\ Banjarmasin, Kalimantan Selatan \\ *E-mail: samsul.hadi@ulm.ac.id
}

Received: 17 September 2021; Accepted: 25 Desember 2021; Published: 31 Desember 2021

\begin{abstract}
Abstrak
Nuclear factor kappa B (NF-kB) adalah faktor transkripsi yang mengatur ekspresi gen yang penting untuk respon imun bawaan dan adaptif. Aktivasi berlebih NF- $\kappa$ B berkaitan dengan penyakit inflamasi contohnya autoimun, lupus eritematosus sistemik (SLE) dan rheumatoid arthritis (RA). Penelitian ini bertujuan melakukan skrining kandungan kimia Combretum indicum terhadap inhibitor NF- $\mathrm{BB}$-inducing kinase. Metode yang digunakan dalam penelitian ini dua yaitu melalui PASSonline dan docking. Metode docking yang dipergunakan adalah PLANTS. Hasil dari PASSonline senyawa yang memiliki nilai P.a diatas 0,7 adalah arachidonic acid, linoleic acid, rutin, methyl urasolate, sedangkan skor docking yang diperoleh adalah asquisqualic acid: -60,0382; arachidonic acid : -100,9410; linoleic acid: -93,8730; rutin : -102,9320; methyl urasolate: $-47,9166$. Nilai skor docking yang negatif ini mengindikasikan adanya reaksi yang terjadi antara senyawa dan target terjadi dengan mudah. Berdasarkan hasil tersebut senyawa yang diprediksi berpotensi sebagai inhibitor NF- $\mathrm{BB}$ adalah Rutin.
\end{abstract}

Kata Kunci: $N F-\kappa B$, C.indicum, Docking

Abstract

Nuclear factor kappa $B(N F-\kappa B)$ is a transcription factor that regulates the expression of genes important for innate and adaptive immune responses. $N F-\kappa B$ overactivation is associated with inflammatory diseases such as autoimmune, systemic lupus erythematosus (SLE) and rheumatoid arthritis (RA). This study aims to screen the chemical content of C.indicum against $N F-\kappa B$-inducing kinase inhibitors. There are two methods used in this study, namely through PASSonline and docking. The docking method used was PLANTS. The results of PASSonline compounds that have P.a values above 0.7 weree arachidonic acid, linoleic acid, rutin, methyl urasolate, while the docking scores obtained were asquisqualic acid: -60.0382; arachidonic acid: -100,9410; linoleic acid: -93.8730; routine : -102,9320; methyl urasolate: $-47,9166$. This negative docking score indicates that the reaction between the compound and the target occurs easily. In conclusion, the compound predicted to have a potential as an inhibitor of $N F-\kappa B$ is Rutin.

Keywords: $N F-\kappa B$, C.indicum, Docking

\section{PENDAHULUAN}

Nuclear factor kappa B (NF- $\kappa$ B) adalah faktor transkripsi yang mengatur ekspresi gen yang penting untuk respon imun bawaan dan adaptif. Aktivasi NF- $\mathrm{NB}$ berperan dalam respon pertahanan, proliferasi limfosit dan inflamasi. NF- $\kappa \mathrm{B}$ termasuk dalam keluarga mitogen-activated protein kinase kinase kinase (MAP3K) (Malinin et al., 1997). NF- $\kappa \mathrm{B}$-inducing kinase (NIK) merupakan protein serin/treonin kinase penting untuk aktivasi $\mathrm{NF}-\kappa \mathrm{B}(\mathrm{NF}-\kappa \mathrm{j} \mathrm{B} 2)$. NIK mengatur NF-кjB2 dengan memfosforilasi proteolitik prekursor p100 ke bentuk aktif p524, yang mengikat DNA dan mengaktifkan transkripsi gen yang di targetkan (Smith et al., 2001).

Aktivasi NF- $\kappa \mathrm{B}$ tergantung pada NIK dalam memperoleh signal aktivitas biologis 
dari jalur BAFF/BAFF-R dan (LT $\alpha / \beta 2) / \mathrm{LT} \beta$ R (Kohno et al., 2008). Signal BAFF-R berperan penting dalam perkembangan dan pematangan sel B perifer. Aktivitas abnormal sel B yang disebabkan oleh kelebihan BAFF dapat menyebabkan penyakit autoimun dan limfoma sel B. Signal LT $\beta$-R berfungsi dalam memperbaiki organogenesis limfoid sekunder, yang sering menjadi ciri khas untuk perkembangan peradangan kronis dan autoimun (Remouchamps et al., 2011). NIK juga menerima signal dari keluarga sitokin TNF, contohnya CD27L,CD40L, TWEAK, and RANKL (akivator reseptor NF- $\mathrm{BB}$ ) hal ini berkaitan dengan penyakit autoimun, osteoporosis dan kanker yang disebabkan oleh Sel B (Bossen et al., 2006). Pengobatan dengan target reseptor $\mathrm{BAFF} / \mathrm{LTb} / \mathrm{TWEAK}$ secara signifikan mengurangi dan bahkan mencegah penyakit lupus eritematosus sistemik (LES) dan rheumatoid arthritis (RA) (Jackson \& Davidson, 2019). Dengan demikian, inhibitor molekul kecil khusus untuk NIK dapat memberikan pendekatan baru dalam intervensi signal dan modulasi NF- $\kappa B$ (Ren et al., 2017). Inhibisi terhadap protein ini membantu apoptosis dan meningkatkan respon sel kanker ketika menjalani terapi kanker, sehingga proses aktivasi protein dan produksi NF- $\mathrm{NB}$ menjadi salah satu target obat antiiflamasi. Molekul kecil yang mempunyai akivitas ini mendorong peneliti melakukan skrining komputasi dengan metode docking dari salah satu tumbuhan yaitu Combretum indicum.

C. indicum merupakan tanaman dengan bunga berwarna pink, putih tergantung varietasnya. Tanaman ini memiliki beberapa khasiat diantaranya bagian akar digunakan untuk rematik, biji atau buah dipergunakan sebagai obat cacing, Rebusan buah juga bisa digunakan untuk berkumur dan juga digunakan untuk faringitis. Daun dipergunakan menurunkan rasa sakit karena demam. Jus dari daunnya digunakan untuk menyembuhkan bisul dan untuk mengobati koreng. Tanaman ini digunakan untuk mengobati hiperlipidemia, asma bronkial, keram perut (Bekele \& Lemma, 2021). Kandungan senyawa dari tanaman ini yaitu asquisqualic acid, arachidonic acid, linoleic acid, rutin dan methyl urasolate, dari kandungan ini yang mempunyai kemampuan dalam pengobatan cacingan adalah quisqualic acid (Pooja, 2016). Bunga dari C.indicum mepunyai kemampuan anti bakteri terhadap Staphylococcus aureus (Zuraida et al., 2017)

\section{METODE PENELITIAN Bahan dan peralatan}

Bahan yang digunakan dalam penelitian ini adalah senyawa yang ditemukan dari $\mathrm{C}$. indicum. Peralatan yang digunakan adalah laptop Aspire ES 14. Software yang dipergunakaan adalah PLANTS (Korb et al., 2009), Marvin bean (ChemAxon, 2016) dan discovery studio (Systèmes, 2020). Webserver yang dipergunakan adalah PASS online.

\section{Cara kerja}

Skrining virtual terhadap inhibitor NF$\kappa \mathrm{B}$ dilakukan menggunakan metode docking. Tahap pertama dalam penelitian ini adalah preparasi NF- $\kappa \mathrm{B}$ dengan kode PDB ID: 4IDV menggunakan yasara yaitu memilih rantai yang ditargetkan. Tahap selanjutnya adalah preparasi ligand dan senyawa aktif menggunakan Marvin bean. Tahap berikutnya penelitian ini adalah redocking untuk memvalidasi metode, koordinat yang dipergunakan adalah X:16,8342; Y: 13,8496; $\mathrm{Z}$ : 87,2754 dan radius yang dipergunakan adalah 12,1842. Setelah metode docking valid maka skrining virtual dapat dilaksanakan. Tahap akhir dalam penelitian ini adalah visualisasi residu dan jarak ikatannya.

\section{Analisis data}

Analisis dengan melihat skor docking yang di atas $80 \%$ dari ligand referensi

Skor docking $=\frac{\text { Skor docking ligand }}{\text { Skor docking referensi }} \times 100 \%$ 


\section{HASIL DAN PEMBAHASAN}

Skrining virtual inhibitor NF- $\kappa$ B dimulai dengan mencari kandungan kimia dari $\mathrm{C}$. indicum. Dari penelusuran daftar pustaka didapatkan 5 senyawa yaitu asquisqualic acid, arachidonic acid, linoleic acid, rutin dan methyl urasolate (Bekele \& Lemma, 2021). Setelah mendapatkan senyawa, selanjutnya adalah membuat struktur dengan bantuan Marvin bean dan disimpan dalam format smile. Format smile ini yang dipakai dalam PASS online untuk memprediksi aktivitas antiinflamasi. Hasil prediksi online dapat dilihat pada Tabel 1. Dari Tabel 1 nilai tertinggi yang mempunyai aktivitas antiinflamasi adalah rutin dan nilai terendah adalah asquisqualic acid. Dan nilai $\mathrm{Pa}$ (Probability to be active) dari semua senyawa yang di skrining menunjukkan nilai Pa lebih besar dari $\mathrm{Pi}$ (probability to be in active), hal ini menunjukkan senyawa ini berpotensi aktif dari pada in aktif. Dari Tabel ini juga diperoleh 4 senyawa nilai $\mathrm{Pa}>0,7$ yaitu arachidonic acid, linoleic acid, rutin, methyl urasolate sehingga empat senyawa ini berpotensi tinggi secara komputasi dan uji laboratorium sebagai antiinflamasi. Sementara asquisqualic acid nilai $\mathrm{Pa}<0,3$, sehingga senyawa ini mempunyai potensi rendah sebagai antiiflamasi baik secara komputasi maupun uji laboratorium (Filimonov et al., 2014; Primadhanty et al., 2020).

Tabel 1. Skrining PASS online

\begin{tabular}{lll}
\hline Senyawa & $\mathbf{P a}$ & $\mathbf{P i}$ \\
\hline asquisqualic acid & 0,222 & 0,156 \\
arachidonic acid & 0,73 & 0,012 \\
linoleic acid & 0,73 & 0,012 \\
rutin & 0,99 & 0 \\
methyl urasolate & 0,859 & 0,005 \\
\hline
\end{tabular}

Setelah dilakukan skrining melalui PASS online untuk melihat prediksi aktivitas antiinflamasi selanjutnya adalah docking untuk melihat stabilitas interaksi antara ligand dengan NF-кB. Sebelum melakukan docking terhadap senyawa dari Combretum indicum terlebih dahulu dilakukan validasi docking menggunakan struktur co-crystal yaitu 4-\{3[2-amino-5-(2-methoxyethoxy)pyrimidin-4yl]-1H-indol-5-yl \}-2-methylbut-3-yn-2-ol. Hasil dari validasi docking memperlihatkan nilai RMSD sebesar $0,2393 \AA$ seperti terlihat pada Gambar 1. Nilai ini di bawah $2 \AA$, sehingga metode ini dapat dikatakan valid (Rodríguez et al., 1989).

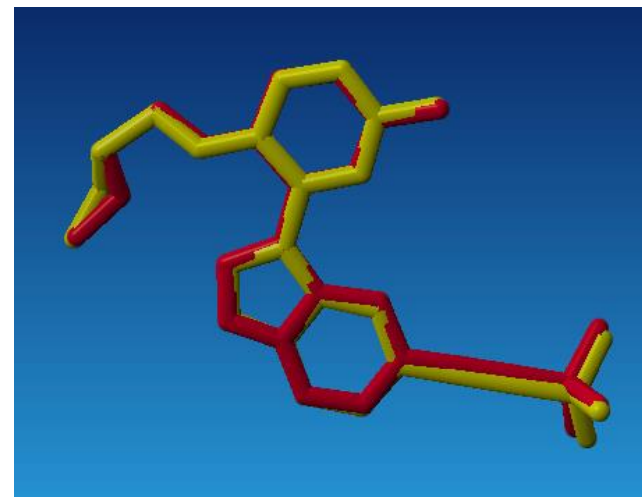

Gambar 1 . Visualisasi redocking

Merah adalah ligand referensi, kuning adalah ligand redocking

Stabilitas interaksi antara ligand dengan protein dapat dilihat dari skor docking. Skor docking negatif menunjukkan semakin stabil dan reaksi yang terjadi semakin mudah dan spontan (Cournia et al., 2017). Skor docking dan tipe residu yang terlibat dapat lihat pada Tabel 1. Skor docking relatif di atas $80 \%$ adalah arachidonic acid dan methyl urasolate. Skor docking dari arachidonic acid disebabkan oleh interaksi hidrofobik tipe alkil-alkil antara ligand dengan ALA443 dengan jarak ikatan 4,99992 $\AA$ dan 3,62564 $\AA$ A; Residu LYS517 jarak 4,60602 ̊, VAL521 jarak 5,21415 ̊, ALA 538 jarak 3,6057 LEU522 jarak 4,93024 ̊. Ikatan Hidrofob dengan tipe pi-alkil terjadi pada HIS513 dengan jarak 4,74373 $\AA$ dan 4,74373 A serta

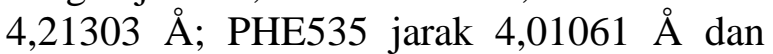
4,96785 A. Jika dikomparatifkan dengan ligand referensi maka memiliki persamaan residu yang berinteraksi yaitu LYS517, ALA538, PHE535. Yang menarik dari ligand ini jika dibandingkan dengan linoleic acid 
adalah terdapat ikatan rangkap pada nomer 5,8,11, 14 sedangkan linoleic acid hanya memiliki ikatan rangkap pada 9 dan 12, hal ini berpengaruh pada tipe interaksi yang terjadi, walaupun memiliki kesamaan residu yang berikatan akan tetapi terdapat perbedaan pada ALA443, HIS513, PHE535, karena arachidonic acid mampu membentuk interaksi lebih dari 1(Tabel 2).

Rutin memiliki skor docking yang bagus karena memiliki ikatan hidrogen yang berasal dari CYS533 atom $\mathrm{H}$ dengan atom $\mathrm{O}$ dari ligand dengan jarak ikatan 2,10764 $\AA$, ASN520 (2,49083 A), ALA531 (2,83007 ̊),
LYS517 (2,18111 ̊), PHE535 (3,07222

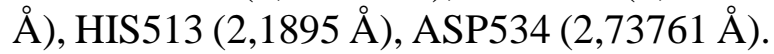
Ikatan hidrogen terjadi antara pi ligand- alkil dari protein yaitu LYS517 jarak ikatan $4,59707 \AA$ A ILE452 (5,36648 ̊), CYS533 $(4,82897 \AA), \operatorname{ILE} 452(5,36648 \AA)$, CYS533 (4,82897 ̊̊), VAL 453 (4,47419 ̊), ALA531 $(4,53039 \AA)$, LEU506 (4,10214 ̊), ALA538 $(4,91563 \AA)$. Jika dikomparatifkan dengan ligand referensi maka memiliki persamaan residu yang berinteraksi yaitu CYS533, ALA531, LYS517, PHE535, ASP534, LEU506, ALA538.

Tabel 2. Skor docking dan residu yang berinteraksi

\begin{tabular}{|c|c|c|c|c|}
\hline \multirow[t]{2}{*}{ Senyawa } & \multirow{2}{*}{$\begin{array}{l}\text { Skor } \\
\text { docking }\end{array}$} & \multicolumn{3}{|c|}{ Tipe ikatan } \\
\hline & & Hidrogen & Hidrofob & $\begin{array}{l}\text { Pi-lone } \\
\text { pair }\end{array}$ \\
\hline $\begin{array}{l}\text { ligand } \\
\text { referensi }\end{array}$ & $-118,2650$ & $\begin{array}{l}\text { ALA531, LYS517, } \\
\text { ALA518, ASP519 }\end{array}$ & $\begin{array}{l}\text { PHE535, ALA443, ALA538, } \\
\text { LEU506, ILE511, HIS513, LEU532, } \\
\text { CYS533 }\end{array}$ & ASP534 \\
\hline $\begin{array}{l}\text { asquisqualic } \\
\text { acid }\end{array}$ & $-60,0382$ & $\begin{array}{l}\text { ASP534, VAL516, } \\
\text { ASN520, ASP515, } \\
\text { ASP534 }\end{array}$ & $\begin{array}{l}\text { LEU532, CYS533, VAL516, } \\
\text { LEU532 }\end{array}$ & ASP534 \\
\hline $\begin{array}{l}\text { arachidonic } \\
\text { acid }\end{array}$ & $-100,9410$ & & $\begin{array}{l}\text { ALA } 443, \text { LYS517, VAL521, } \\
\text { ALA538, LEU522, HIS513, PHE535 }\end{array}$ & \\
\hline linoleic acid & $-93,8730$ & & $\begin{array}{l}\text { ALA } 443, \text { LYS517, VAL521, } \\
\text { ALA538, LEU522, HIS513, PHE535 }\end{array}$ & \\
\hline rutin & $-102,9320$ & $\begin{array}{l}\text { CYS533, ASN520, } \\
\text { ALA531, LYS517, } \\
\text { PHE535, HIS513, } \\
\text { ASP534 }\end{array}$ & $\begin{array}{l}\text { LYS517, ILE452, CYS533, } \\
\text { VAL453, ALA531, CYS533, } \\
\text { LEU506, ALA538 }\end{array}$ & \\
\hline $\begin{array}{l}\text { methyl } \\
\text { urasolate }\end{array}$ & $-47,9166$ & HIS537 & $\begin{array}{l}\text { VAL516, VAL521, LEU522, } \\
\text { CYS533, ALA538, LEU522, } \\
\text { LEU532, LEU477, LEU522, } \\
\text { HIS513, PHE535 }\end{array}$ & \\
\hline
\end{tabular}

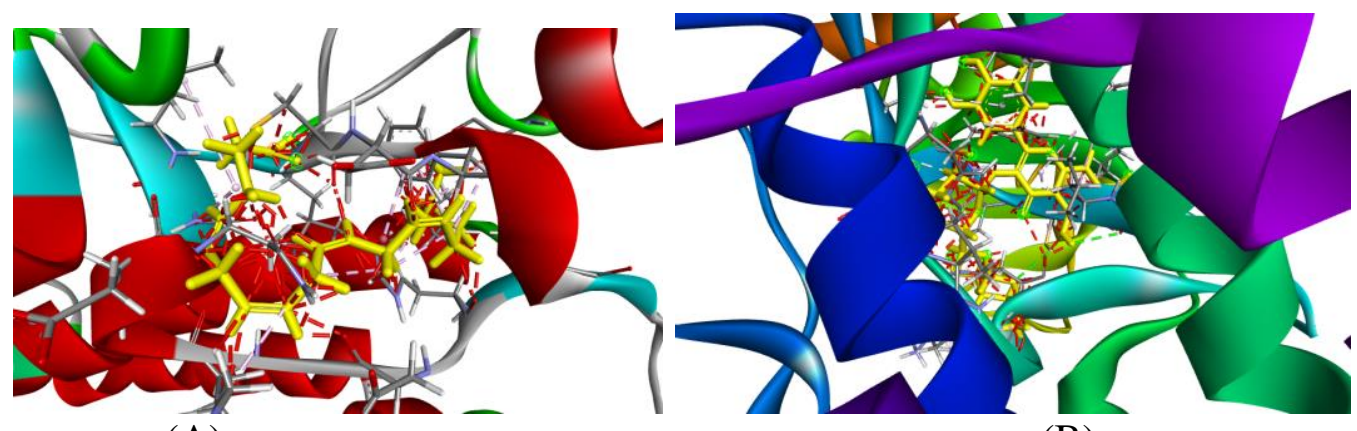

(A)
(B)

Gambar 2. Visualisasi 3D Kuning adalah ligand ; (A) interaksi Arachidonic acid dengan NF-кB; (B) interaksi rutin dengan NF-кb 
Arachidonic acid walaupun mempunyai nilai $\mathrm{Pa}$ tinggi dan mempunyai stabilitas interaksi yang baik, tetapi senyawa ini merupakan asam lemak tak jenuh ganda yang terikat secara kovalen dalam bentuk esterifikasi di membran sel tubuh. Setelah iritasi atau cedera, asam arakidonat dilepaskan dan dioksigenasi oleh sistem enzim yang mengarah pada pembentukan kelompok mediator inflamasi yaitu eikosanoid. Eikosanoid merupakan dasar dari proses inflamasi (Higgins \& Lees, 1984) yang dengan adanya enzim lipooksigenase, eikosanoid dikatalisis menjadi prostaglandin E2 dan prostanoid lainnya. Salah satu mekanisme obat antiinflamasi nonsteroid menghasilkan penghambatan sintesis prostaglandin dengan menginhibisi siklooksigenase, sehingga saat ini salah satu pendekatan antiinflamasi adalah mengganggu metabolisme arachidonic acid khususnya inflamasi kronis karena senyawa ini bekerja di daerah jalur utama inflamasi (Sugimoto et al., 2016). Sehingga arachidonic acid bekerja sebagai agonis dari inflamasi. Sedangkan skor docking dari rutin yang bagus ini, berkolerasi dengan aksi antinflamasi melalui mekanisme penurunan produksi nitrit oxide (NO) dan
TNF $\alpha$ pada neutrophil dengan konsentrasi $100 \mu \mathrm{M}$ (Nikfarjam et al., 2017).

Active site $\mathrm{NF}-\kappa \mathrm{B}$ memiliki pengaruh yang besar karena adanya residu SER177, CYS179 dan SER 188 (Gilmore \& Herscovitch, 2006) merupakan bagian dari loop aktivasi kinase dan diperlukan untuk aktivasi IKK $\beta$ dalam merespon signal TNF dan LPS ketika terjadi inisiasi inflamasi (Perkins, 2006) namun karena berbeda koordinat dengan situs pengikatan co-cystal yaitu 4-\{3-[2-amino-5-(2methoxyethoxy)pyrimidin-4-yl]-1H-indol-5yl \}-2-methylbut-3-yn-2-ol maka interaksi ini tidak terlihat pada interaksi arachidonic acid atau rutin(Gambar 2). Sehingga berdasarkan data diatas dan informasi tentang arachidonic acid maka senyawa yang berpotensi sebagai inhibitor NF- $\kappa \mathrm{B}$ secara komputasi adalah rutin.

\section{KESIMPULAN}

Senyawa yang berpotensi sebagai inhibitor NF- $\kappa \mathrm{B}$ secara komputasi adalah rutin

\section{Daftar Pustaka}

Bekele, B., \& Lemma, B., 2021. Bioactive compounds from ten species of the genus Combretum : Review. 5(1), 18-30.

Bossen, C., Ingold, K., Tardivel, A., Bodmer, J.-L., Gaide, O., Hertig, S., Ambrose, C., Tschopp, J., \& Schneider, P., 2006. Interactions of tumor necrosis factor (TNF) and TNF receptor family members in the mouse and human. The Journal of Biological Chemistry, 281(20), 13964-13971.

ChemAxon., 2016. ChemAxon - Software Solutions and Services for Chemistry and Biology. In MarvinSketch, Version 16.10.31. https://chemaxon.com/

Cournia, Z., Allen, B., \& Sherman, W., 2017. Relative Binding Free Energy Calculations in Drug Discovery: Recent Advances and Practical Considerations. Journal of Chemical Information and Modeling, 57(12), 2911-2937.

Filimonov, D. A., Lagunin, A. A., Gloriozova, T. A., Rudik, A. V, Druzhilovskii, D. S., Pogodin, P. V, \& Poroikov, V. V., 2014. Prediction of the Biological Activity Spectra of 
Organic Compounds Using the Pass Online Web Resource. Chemistry of Heterocyclic Compounds, 50(3), 444-457

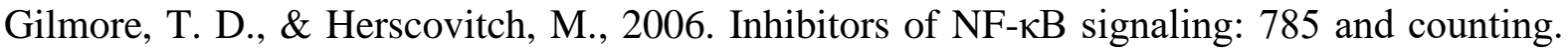
Oncogene, 25(51), 6887-6899.

Higgins, A. J., \& Lees, P., 1984. The acute inflammatory process, arachidonic acid metabolism and the mode of action of anti-inflammatory drugs. Equine Veterinary Journal, 16(3), $163-175$.

Jackson, S. W., \& Davidson, A., 2019. BAFF inhibition in SLE-Is tolerance restored? Immunological Reviews, 292(1), 102-119.

Kohno, T., Daa, T., Otani, H., Shimokawa, I., Yokoyama, S., \& Matsuyama, T., 2008. Aberrant expression of BAFF receptor, a member of the tumor necrosis factor receptor family, in malignant cells of nonhematopoietic origins. Genes to Cells : Devoted to Molecular \& Cellular Mechanisms, 13(10), 1061-1073.

Korb, O., Stützle, T., \& Exner, T. E., 2009. Empirical scoring functions for advanced ProteinLigand docking with PLANTS. Journal of Chemical Information and Modeling, 49(1), 84-96.

Malinin, N. L., Boldin, M. P., Kovalenko, A. V, \& Wallach, D., 1997. MAP3K-related kinase involved in NF-kappaB induction by TNF, CD95 and IL-1. Nature, 385(6616), 540-544.

Nikfarjam, B. A., Adineh, M., Hajiali, F., \& Nassiri-Asl, M., 2017. Treatment with Rutin - A Therapeutic Strategy for Neutrophil-Mediated Inflammatory and Autoimmune Diseases: - Anti-inflammatory Effects of Rutin on Neutrophils. Journal of Pharmacopuncture, 20(1), 52-56.

Perkins, N. D., 2006. Post-translational modifications regulating the activity and function of the nuclear factor kappa B pathway. Oncogene, 25(51), 6717-6730.

Pooja, S. S., 2016. A brief review on pharmacological studies of Combretum indicum in development of pharmaceutical formulation for challenging. World Journal of Pharmacy and Pharmaceutical Sciences, 5(6), 500-507.

Primadhanty, B., Adniana, N., Pk, H., Utomo, D. H., \& Yustin, E., 2020. Analisis In Silico Pada Virgin Coconut Oil ( VCO ) Untuk Terapi Dermatitis Atopik. Medicinus, 33(3), 3237.

Remouchamps, C., Boutaffala, L., Ganeff, C., \& Dejardin, E., 2011. Biology and signal transduction pathways of the Lymphotoxin- $\alpha \beta / \mathrm{LT} \beta \mathrm{R}$ system. Cytokine \& Growth Factor Reviews, 22(5-6), 301-310.

Ren, X., Li, X., Jia, L., Chen, D., Hou, H., Rui, L., Zhao, Y., \& Chen, Z., 2017. A smallmolecule inhibitor of NF- $\mathrm{BB}$-inducing kinase (NIK) protects liver from toxin-induced inflammation, oxidative stress, and injury. FASEB Journal: Official Publication of the Federation of American Societies for Experimental Biology, 31(2), 711-718. 
Rodríguez, E., Arqués, J. L., Rodríguez, R., Nuñez, M., Medina, M., Talarico, T. L., Casas, I. A., Chung, T. C., Dobrogosz, W. J., Axelsson, L., Lindgren, S. E., Dobrogosz, W. J., Kerkeni, L., Ruano, P., Delgado, L. L., Picco, S., Villegas, L., Tonelli, F., Merlo, M., ... Masuelli, M., 1989. Protein-Protein and Protein-Ligand Docking. Intech, 32(tourism), $137-144$.

Smith, C., Andreakos, E., Crawley, J. B., Brennan, F. M., Feldmann, M., \& Foxwell, B. M., 2001. NF-kappaB-inducing kinase is dispensable for activation of NF-kappaB in inflammatory settings but essential for lymphotoxin beta receptor activation of NFkappaB in primary human fibroblasts. Journal of Immunology (Baltimore, Md. : 1950), 167(10), 5895-5903.

Sugimoto, M. A., Sousa, L. P., Pinho, V., Perretti, M., \& Teixeira, M. M., 2016. Resolution of Inflammation: What Controls Its Onset? . In Frontiers in Immunology (Vol. 7, p. 160).

Systèmes, D., 2020. Free Download: BIOVIA Discovery Studio Visualizer - Dassault Systèmes. https://discover.3ds.com/discovery-studio-visualizerdownload\#_ga=2.4935860.685747970.1587999055-a5d1c1c0-3176-11e9-a86fe302515d21c8

Zuraida, Riniwasih, L., \& Hartanti, D., 2017. Uji efektifitas ekstrak etanol bunga ceguk (Combretum indicum L.) dalam bentuk sedian gel antiseptic tangan dengan metode replika. Indonesia Natural Research Pharmaceutical Journal, 2(1), 64-72. 